\title{
Lift-to-Drag Ratio of the Application of Hydrofoil With Variation Mounted Position on High-Speed Patrol Vessel
}

\author{
Muhammad Arif Budiyanto ${ }^{1, *}$, Naufal Yudha Prawira ${ }^{1}$, Haekal Dwiputra $^{1}$ \\ 1 Naval Architecture and Marine Engineering, Department of Mechanical Engineering, Universitas Indonesia, Kampus Baru UI Depok, Jawa Barat, \\ 16424, Indonesia
}

\section{ARTICLE INFO}

\section{Article history:}

Received 24 March 2021

Received in revised form 25 May 2021

Accepted 26 May 2021

Available online 28 May 2021

\section{Keywords:}

Hydrofoils; patrol vessel; lift-to-drag ratio

\section{ABSTRACT}

\begin{abstract}
The hydrofoil is one of the hydrodynamic support technologies for marine vehicles that provide a high performance and are feasible to operate. The mounting position of hydrofoils on the hull is one of the keys to improving the hydrodynamic performance, where the existing academic literature to find the optimum position of hydrodynamic is still deficient. The objective of this study is to compare the mounting locations of hydrofoil in the horizontal axis in a high-speed patrol vessel. The comparison result is based on the computational fluid dynamics where the basic model was validated using experimental data. Three mounting location cases of hydrofoils were performed i.e. middle section, stern section, and behind the stern. The result shows that the optimal hydrofoil mounting position is after the transom. In this position, the value of the liftto-drag ratio is higher by an average of $10 \%-29 \%$ compared to other positions depending on the speed of the ship.
\end{abstract}

\section{Introduction}

In recent decades, the use of planing hulls on high-speed vessels continues to grow not only for the military but also for passenger ships. Research continues to be carried out to obtain a reliable design and performance in terms of durability and seakeeping performance [1]. Research on the planing hull was first carried out by Savitsky who carried out a series of tests on the flat plate model so that he could determine the coefficient of a practical ship shape [2]. The development of the planing hull model continues to be carried out by other researchers in order to analyze its hydrodynamic characteristics, this research was conducted experimentally which resulted in an effective deadrise angle database for the planing hull [3]. The further development of the planing hull model was carried out by other researchers by adding hydrofoils with a deep $V$ shape for patrol boats with a research focus on the aspect ratios and bottom deadrise angles $[4,5]$.

Research on planning hull continues to be carried out until now both through experiments and simulations with advances in seakeeping performance $[6,7]$. Experimental methods have been widely researched carried out from the beginning development of planing hull models, but due to the high

\footnotetext{
* Corresponding author.

E-mail address: arif@eng.ui.ac.id (Muhammad Arif Budiyanto)
} 
cost of experiments [8], this method is decreased only for data validation. With the development of computer technology so rapidly, in the last decade research with Computational Fluid Dynamics (CFD) has increased more and more. The use of CFD methods with Reynolds-averaged Navier - Stokes equations on unsteady flow has led to numerous high-speed craft studies with accurate results [9]. Some research related to high-speed craft begins with a simulation with Wigley's hull model to predict pitch and heave movements [10]. In addition, other research with CFD has also been carried out to predict ship motion on a high-speed catamaran and shows a good agreement between experimental and numerical data [11], this shows that the CFD method can also be applied to predict the motion of ships.

Focus on the research of planing hull models with hydrofoils, several researchers have tried to investigate the effect of a hydrofoil on the ship resistance $[12,13]$, the results show that the use of hydrofoil can reduce ship resistance by $5.5 \%$ [14]. The results of other investigations show that the use of hydrofoil can also affect ship motion [15], particularly on heaving and pitching, the result showed the back foil gives a better response amplitude operator for heave movement [16]. Another research about hydrofoil that has been done a lot is the effect of angle of attack on foil using NACA profiles [17]. The optimum angle of attack of the hydrofoil will get down when increasing the hull speed, at the specific speed, the hydrofoil will lose the lift force. Total ship reduction the addition of a hydrofoil ranges from $10 \%$ to $28 \%$ depending on variations in the angle of attack $[18,19]$. Another factor on the effectiveness of hydrofoils is regarding the ship's draft [20], from the results of previous studies showing that the ship's draft at full load will increase the effectiveness of using hydrofoil in reducing total resistance by up to $24 \%$ [21]. Another study also showed that the position of the foil in the vertical direction also had an effect on hydrodynamic performance [22]. The optimum position of hydrofoil was when it was fully submerged at an angle of 36 degrees at the speed 30 knots [23]. There are still very few researchers investigating the effect of the hydrofoil position in the horizontal direction.

The objective of this study is to investigate the effect of application hydrofoils in high-speed patrol vessel focusing on the comparison of the mounting locations of the hydrofoil in the horizontal axis. This research will provide twofold contributions which are finding the optimal position of hydrofoil mounting and how much total drag reduction effect of the lift-to-drag ratio.

\section{Description of Simulation Model}

\subsection{Particular Dimension of the Ship Models}

In this study, the high-speed planing hull models were used to investigate the optimal mounting location of the hydrofoils. The model was based on the class of patrol vessels with the semi planing hull called Mark VI. The particular dimension of this vessel are length $25.8 \mathrm{~m}$, beam $6.2 \mathrm{~m}$, draught $1.2 \mathrm{~m}$ and Speed 45 knots which is categorized as high speed craft category in accordance with International Maritime Organization regulations. The body plan of this high-speed vessel is shown in Figure 1. Experimental testing has been carried out in previous studies using a 1:25 scale model, later the data from these experiments will be used for validation in this study. 


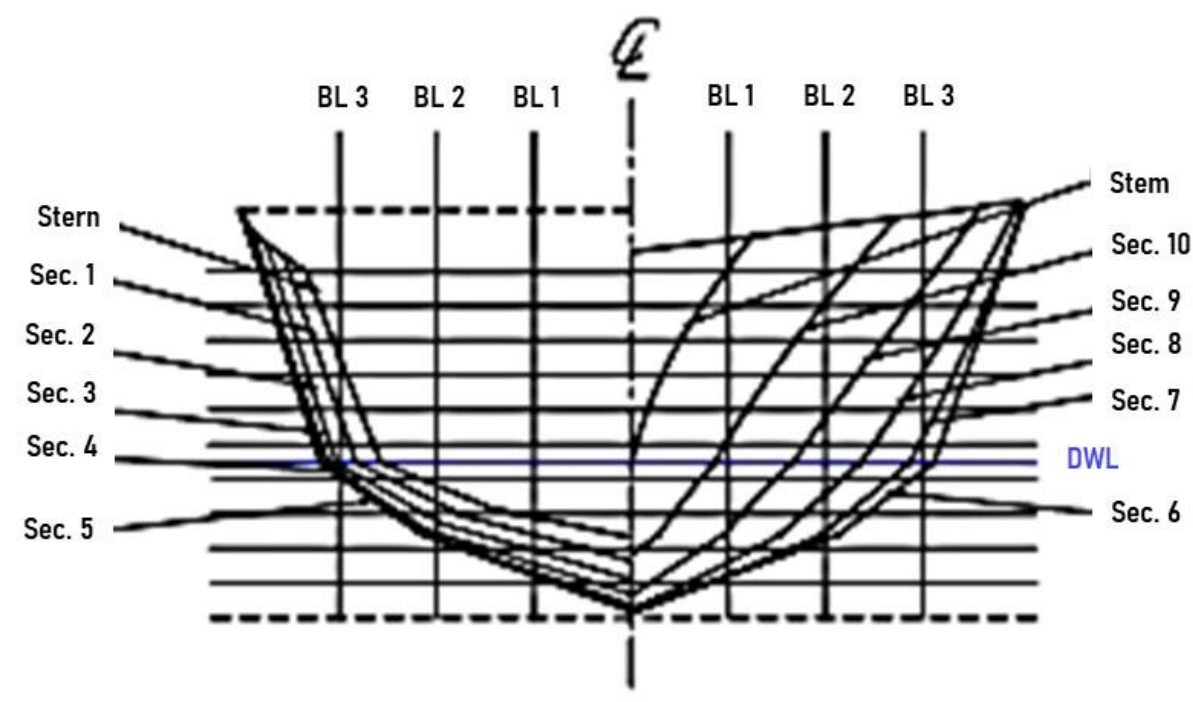

Fig. 1. Body plan of the ship model

In this study, the NACA 4412 profile will be used as hydrofoils at the three different mounting locations on the horizontal axis as shown in the Figure 2. The first consideration of the mounting location is at the midship section (F1) since the location of the longitudinal centre of gravity. The second mounting location is below the transom (F2) and the third mounting location is after the transom (F3). In the vertical axis, all the mounting location has same depth at 1.5 draught and same angle of attack at $0^{\circ}$ with full load draft condition. The dimension of the hydrofoil profile as follows: NACA 4412 profile, Span $0.2 \mathrm{~m}$, Chord $0.04 \mathrm{~m}$, Strut $0.06 \mathrm{~m}$, Surface Area $0.008 \mathrm{~m} 2$, Aspect Ratio 5 and Lift Coefficient 0.47 [24].

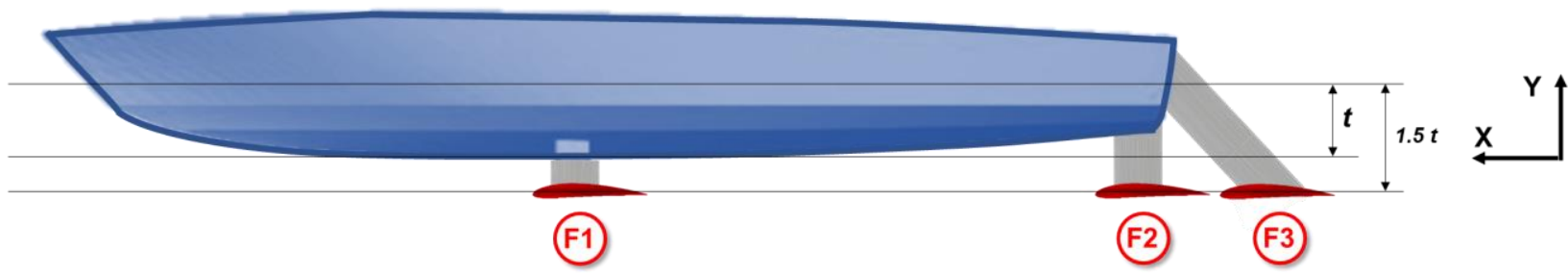

Fig. 2. Three different mounting locations of the hydrofoils

\subsection{Description of the Simulation Model}

The CFD simulation model was carried out by the academic software package called CFDSOF which is based on fluid flow governing equations [25]. The geometrical domain and boundary condition of the simulation model is shown in Figure 3. The dimension of the domain is $13 \mathrm{mx} 7 \mathrm{mx}$ $6.5 \mathrm{~m}$ consist of the body of the ship model, hydrofoil, water, and air within the boundary condition are the inlet, outlet, and slip wall. In ship geometry, the refinement parameter given to the surface of the ship is surface refinement level 5 . As for the stern foil geometry, the surface refinement given is level 7 because the stern foil has a complex shape and is passed through water fluids on all its surfaces. Therefore, a higher level is needed compared to the ship's geometry so that the shape of the hydrofoil can be captured properly. The refinement region given in the whole domain is level 2 with inside mode. 
Boundary condition settings are performed on each face. Inlet uses the type of velocity inlet and the speed entered according to the speed of the ship. The outlet uses the type of outflow and the speed entered according to the ship's speed. For faces of symmetry type, the boundary condition type is symmetry. In boundary typefaces use far-field suitable for compressible (air) fluids. For the fluid flow in the simulation to be constant, it is necessary to adjust the initial condition where the initial speed is entered according to the speed of the ship in the $x$ direction. The simulation is done with physical time 5 seconds, with time-step (delta t) 1e-4, and maximum courant number 1 . The calculation will be saved every run time 0.1 seconds. Within 5 seconds, it is expected that the resistance value graph is nearing a steady phase.

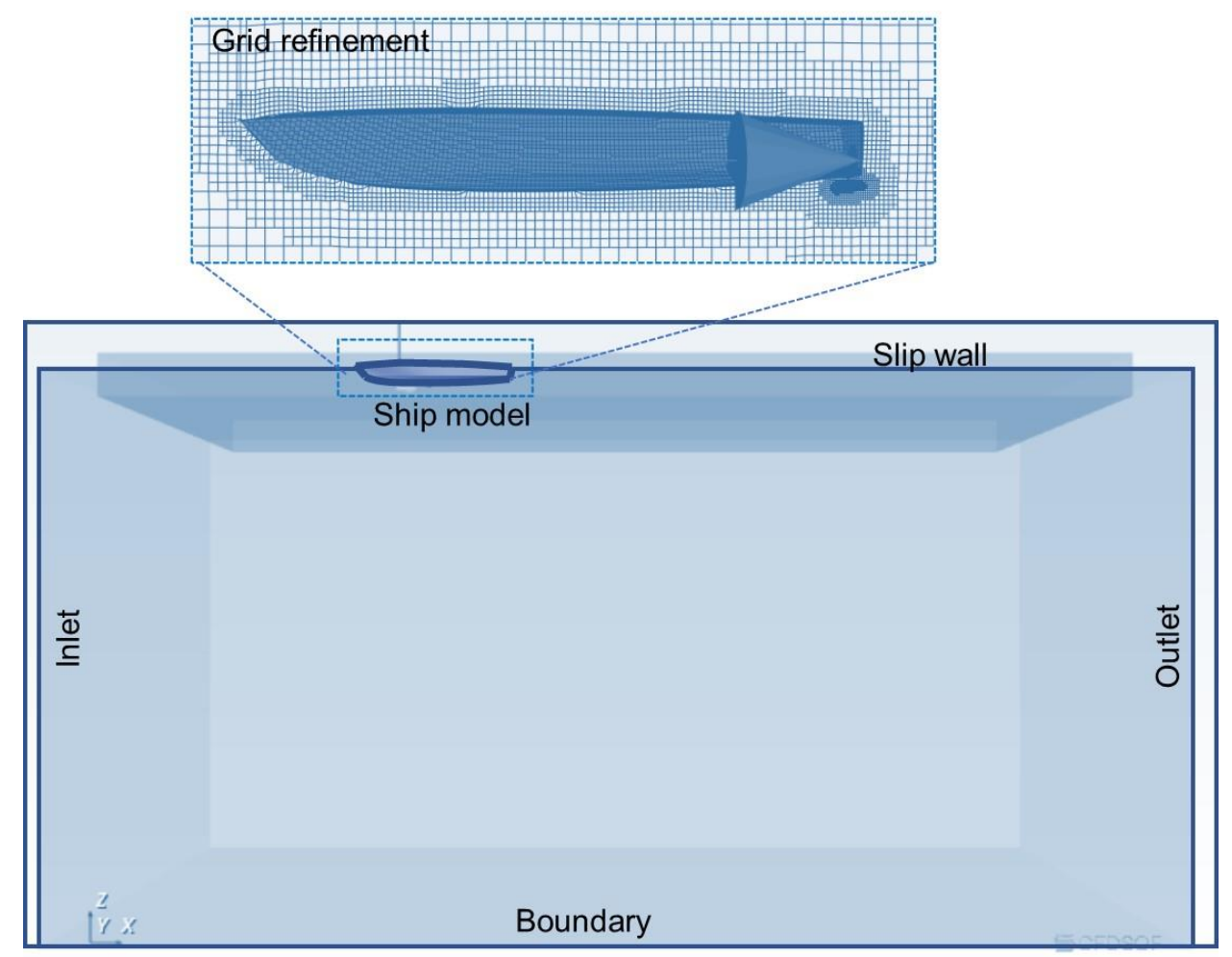

Fig. 3. Geometrical domain and boundary condition of the simulation model

The governing equation of this simulation is determining the simulation model. In this case the transient model will be done where the value of the resistance will change depending on the time. The turbulence model used is RANS (Reynolds-averaged-Navier-Strokes) with the SST k- $\omega$ model are shown in Eq. (1) and Eq. (2)

$$
\begin{aligned}
& \frac{\partial_{(\rho k)}}{\partial_{t}}+\frac{\partial_{\left(\rho u_{j} k\right)}}{\partial x_{j}}=P-\beta^{*} \rho \omega k+\frac{\partial}{\partial x_{j}}\left[\left(\mu+\sigma_{k} \frac{\rho k}{\omega}\right) \frac{\partial k}{\partial x_{j}}\right] \\
& \frac{\partial_{(\rho k)}}{\partial_{t}}+\frac{\partial_{\left(\rho u_{j} \omega\right)}}{\partial x_{j}}=\frac{\gamma \omega}{k} P-\beta \rho \omega^{2}+\frac{\partial}{\partial x_{j}}\left[\left(\mu+\sigma_{\omega} \frac{\rho k}{\omega}\right) \frac{\partial k}{\partial x_{j}}\right]+\frac{\rho \sigma_{d}}{\omega} \frac{\partial k}{\partial x_{j}} \frac{\partial \omega}{\partial x_{j}}
\end{aligned}
$$

where $\beta, \beta^{*}, \gamma, \sigma \mathrm{k}$, and $\sigma \mathrm{d}$ are closure constant coefficient and $P=\tau_{i j} \frac{\partial U_{i}}{\partial x_{j}}$, this simulation was incompressible flow, so $P=0$. Model boundary conditions in Figure 4 Followed ITTC standard [26] for simulation. This model does not focus on details in turbulent fluctuations, so it is enough to simply time-averaged flow properties such as average velocity, pressure, etc. Because the simulation will be 
carried out in two phases (i.e. water and air), the multiphase volume of fluid (VOF) option is used. Phase 1 is defined as a water fluid with a density of $997.13 \mathrm{~kg} / \mathrm{m} 3$ and a dynamic viscosity of 8.91e4 Pa.s. Phase 2 is defined as a water fluid with a density of $1,225 \mathrm{~kg} / \mathrm{m} 3$ and a dynamic viscosity of 1.79e-5 Pa.s.

Paraview is used to visualize the simulation results and calculate the value of the ship's resistance. After the simulation is computed, the ship and the stern foil can be visualized with various options such as pressure, alpha phase, and others. To calculate resistance, it is necessary to calculate the normal force of the $x$ direction which can be generated with Generate Surfaces Normal. Then the results of the pressure that has been obtained from the simulation, multiplied by the magnitude of the normal force of the $x$ direction, then integrated.

\subsection{Grid Independency Test and Validation Result}

Grid Independency Test is a test conducted on a variety of mesh counts which is important to see the sensitivity of the mesh system model to the simulation results. This is done so that we get the right amount of mesh for effective computing time and quality results. The design used for the independence test on CFDSOF and experimental data found previous studies using a resistance load cell in the experiment basin where the ship is driven by an external propulsion which will be connected to the data capture device on board [27]. From the above test, it can be concluded that the most appropriate mesh number is $\pm 350,000$ with a computing time of 24 to 25 hours as shown in Table 1.

Table 1

Grid independency test

\begin{tabular}{llll}
\hline Number of mesh & Simulation & Experiment & Error \\
\hline 15000 & 8 & 4.6 & $73.91 \%$ \\
25000 & 6.8 & 4.6 & $48.69 \%$ \\
35000 & 5 & 4.6 & $8.69 \%$ \\
\hline
\end{tabular}

Validation analysis is done by comparing ship experimental data that was carried out from the previous research with ship simulation data without using stern foil. The validation result show in the Figure 4. From these data, it appears that the trendline between the results of simulation and experiment in a good agreement. So it can be assumed that the setup used in the simulation model is valid. The slight difference in the value of the results of simulations and experiments occur because of numerical factors in the form of viscous layers in meshing. To get the value of resistance, meshing on the surface of the ship is very influential so that the fluid can be "captured" in detail by the surface of the ship. The amount of fluid that is caught is very sensitive to the resistance results obtained. 


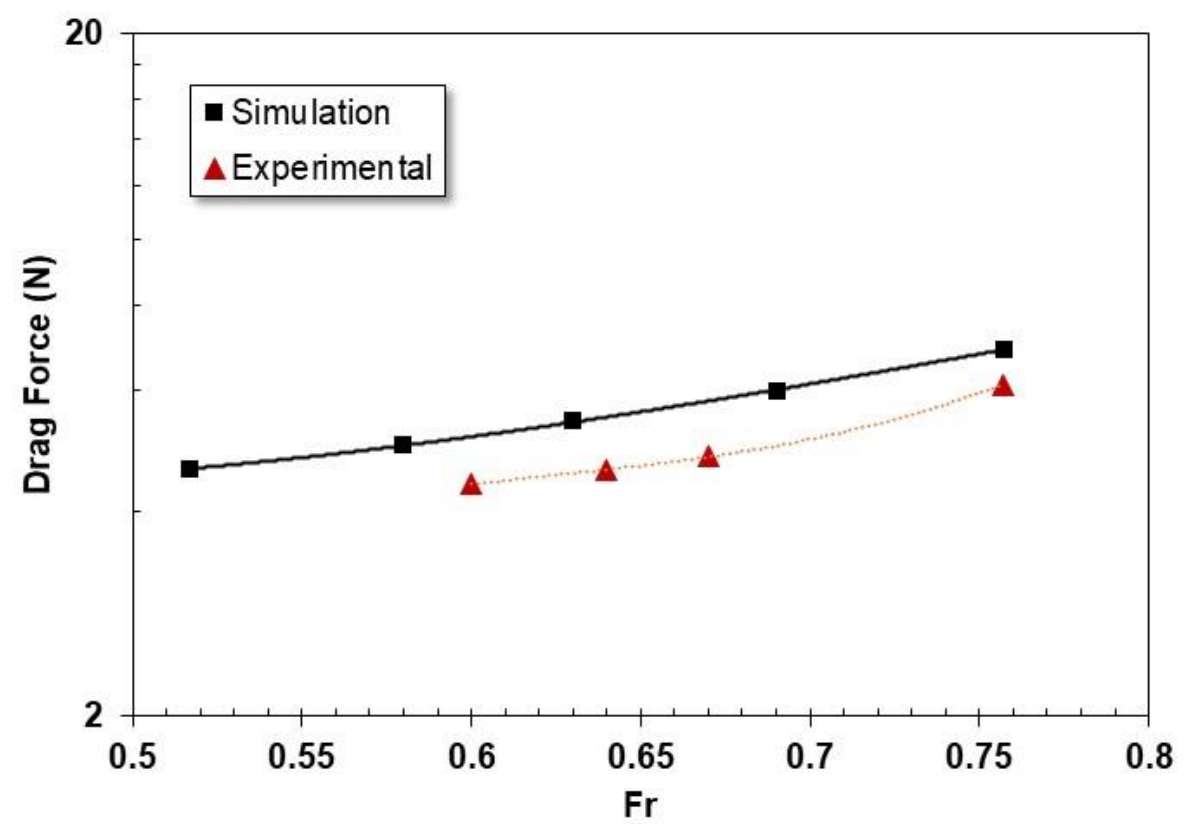

Fig. 4. Comparison of simulation result with experiment data

\section{Results and Discussion}

\subsection{Effect of the Hydrofoil to the Drag Force}

Figure 5 shows the drag force of the ship model with various Froude number. These results indicate clear results that the use of hydrofoil can reduce the value of ship resistance. The optimal mounting location of the hydrofoil to drag reduction located after the transom. The amount of drag reduction for hydrofoil installations at locations F1, F2 and F3 is $11 \%, 25 \%$ and $30 \%$, respectively, depending on the speed of the ship. These results are consistent with research conducted by other researchers who offer a after transom hydrofoil called Hull Vane ${ }^{\circledR}$ with a drag reduction of up to $23 \%$ $[28,29]$.

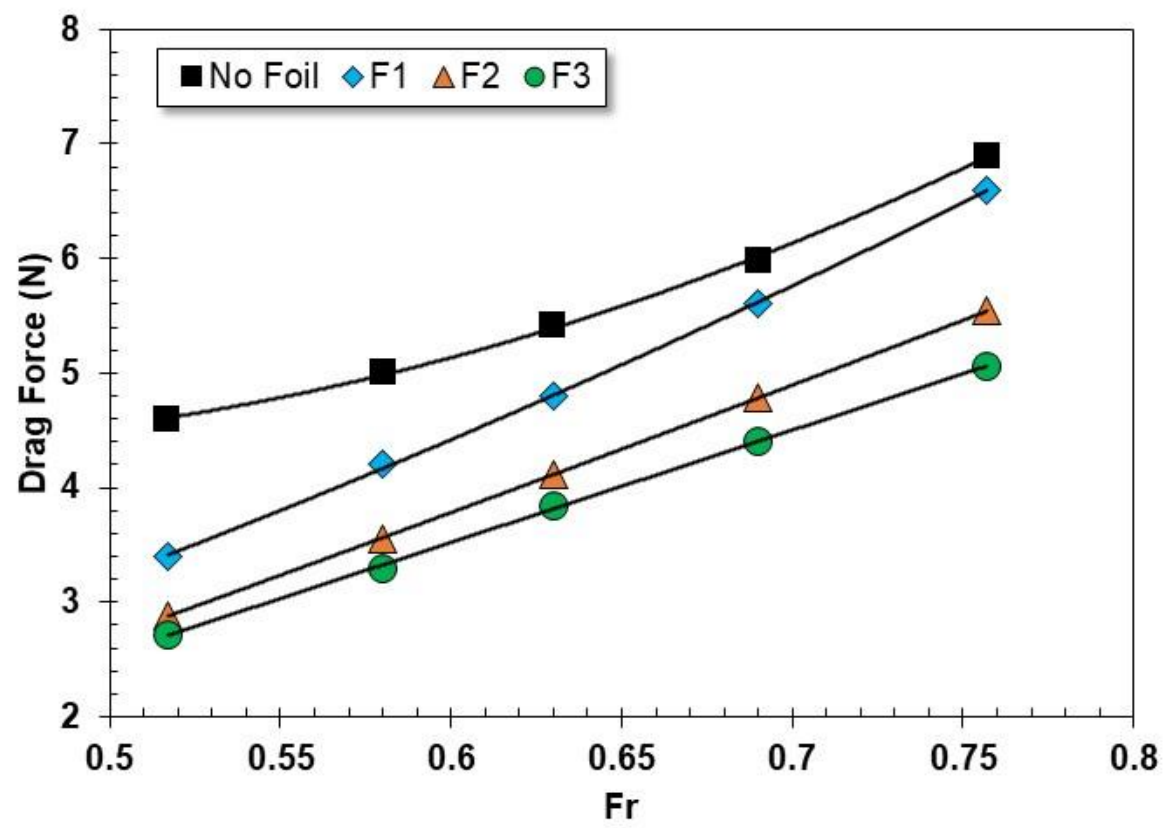

Fig. 5. Effectiveness angle of attack of the application stern foil 


\subsection{Lift-to-Drag Ratio of the Application of Hydrofoil}

Figure 6 shows the lift-to-drag ratio with various Froude number. The lift-to-drag ratio has decreased along the increasing of the Froude number. These results are consistent with research conducted by other researchers shows that the effectiveness of the hydrofoil at a certain speed will decrease depending proportion of trim angle of the ship and the angle of attack of the foil [30]. The lowest trendline of lift-to-drag ratio shown in the mounting location of hydrofoil on the middle section (F1), while the highest lift-to-drag ratio was at the location after the transom (F3). Figure 7 shows speed contour of the mounting location of hydrofoil after the transom at Fr 0.52, where at this point the largest lift-to-drag ratio is obtained. From this speed contour, it is very clear that the mounting location of hydrofoil after the transom can reduce the flow velocity behind the ship, which reduce the formation of ship wave resistance, consistent with the other researcher result. Thus the results of this study confirm that the most optimal mounting location for hydrofoil is after of the transom (F3).

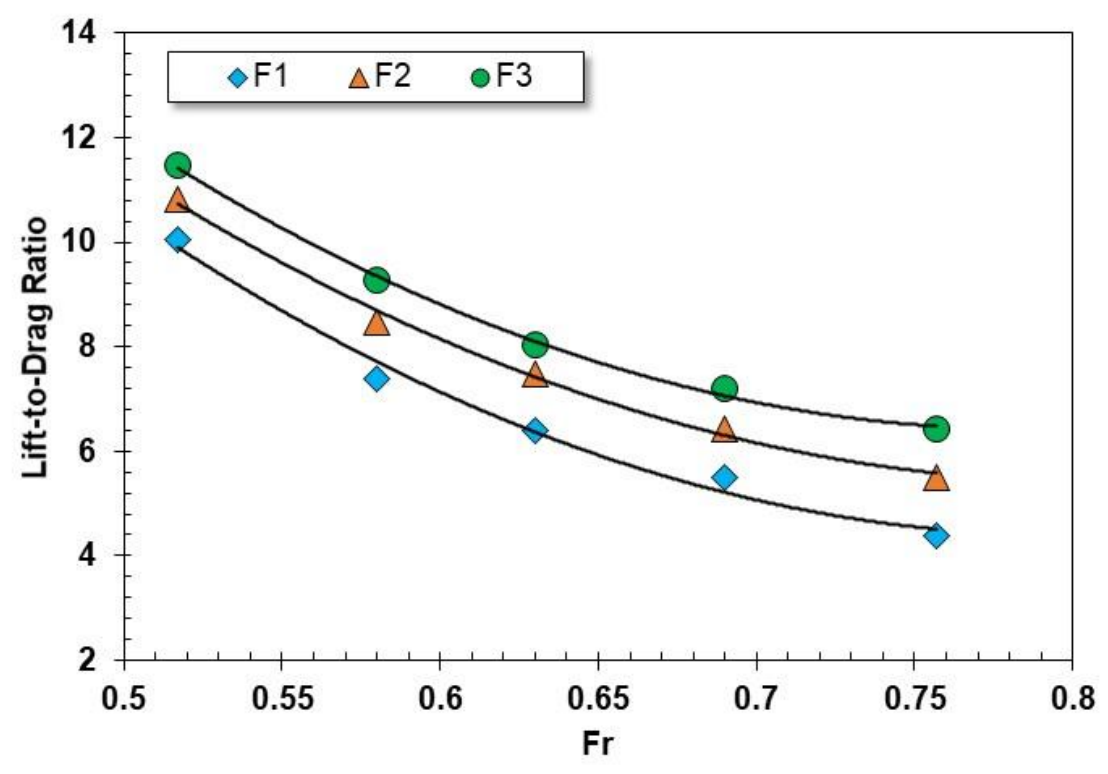

Fig. 6. Lift to drag ratio of the application of hydrofoil

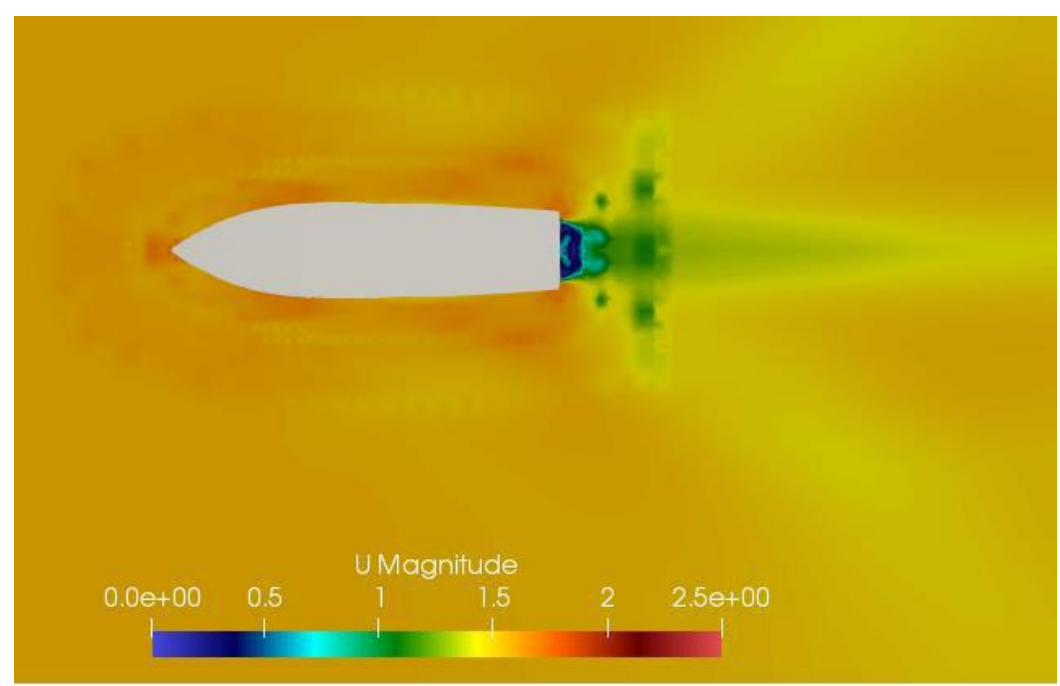

Fig. 7. Speed contour of the mounting location of hydrofoil after the transom at Fr 0.52 


\section{Conclusions}

The study on the comparison of the mounting location of hydrofoils on high-speed patrol vessels has been done carried out using CFD simulation where the basic model was validated using experimental data. The CFD simulation results on the high-speed patrol vessel have a good agreement with the experimental data. Three cases of the mounting location of hydrofoil were performed that is at the midship section, under the transom, and after the transom. From the three cases of the mounting location of a hydrofoil on high-speed patrol vessels, the results consistently showed a drag reduction by $11-30 \%$. From the analysis results of the lift-to-drag ratio, it shows that the most optimal mounting location of hydrofoil is after the transom on Froude number 0.52. From this study, it provides further research directions that lead to the effect of ship motion due to the addition of foil under the hull.

\section{Acknowledgement}

The author is very grateful to PT. CCIT Group Indonesia has provided CFDSOF software (cfdsof.com) for this research. The author also thanks and gives recognition to the Directorate of Research and Development (DRPM) University of Indonesia by PUTI Q3 NKB-2011/UN2.RST/HKP.05.00/2020.

\section{References}

[1] Jewell, D. A. "Hydrofoil Performance in Rough Water." Journal of Hydronautics 9, no. 4 (1975): $142-148$. https://doi.org/10.2514/3.63036

[2] Savitsky, Daniel. "Hydrodynamic design of planing hulls." Marine Technology and SNAME News 1, no. 04 (1964): 71-95. https://doi.org/10.5957/mt1.1964.1.4.71

[3] Keuning, J. A., and J. Gerritsma. "Resistance tests of a series of planing hull forms with 25 degrees deadrise angle." (1982). https://doi.org/10.3233/ISP-1982-2933701

[4] Holling, Henry D., and E. Nadine Hubble. "Model resistance data of Series 65 hull forms applicable to hydrofoils and planing craft." NASA STI/Recon Technical Report N 75 (1974): 16690.

[5] Budiyanto, Muhammad Arif, Hadi Tresno Wibowo, Fadhil Naufal, and Rizqy Obindias. "Study on the effectiveness of a stern-foil on a multi-chine hulls." In IOP Conference Series: Materials Science and Engineering, vol. 1034, no. 1, p. 012064. IOP Publishing, 2021. https://doi.org/10.1088/1757-899X/1034/1/012064

[6] Kim, Dong Jin, Sun Young Kim, Young Jun You, Key Pyo Rhee, Seong Hwan Kim, and Yeon Gyu Kim. "Design of highspeed planing hulls for the improvement of resistance and seakeeping performance." International Journal of Naval Architecture and Ocean Engineering 5, no. 1 (2013): 161-177. https://doi.org/10.2478/ijnaoe-2013-0124

[7] Judge, Carolyn, Maysam Mousaviraad, Frederick Stern, Evan Lee, Anne Fullerton, Jayson Geiser, Christine Schleicher et al. "Experiments and CFD of a high-speed deep-V planing hull-Part I: Calm water." Applied Ocean Research 96 (2020): 102060. https://doi.org/10.1016/i.apor.2020.102060

[8] Gomit, Guillaume, Ludovic Chatellier, Damien Calluaud, Laurent David, Didier Fréchou, Romuald Boucheron, Olivier Perelman, and Christian Hubert. "Large-scale free surface measurement for the analysis of ship waves in a towing tank." Experiments in Fluids 56 (2015): 1-13. https://doi.org/10.1007/s00348-015-2054-z

[9] Khazaee, Reza, Mohammad Amin Rahmansetayesh, and Sajad Hajizadeh. "Hydrodynamic evaluation of a planing hull in calm water using RANS and Savitsky's method." Ocean Engineering 187 (2019): 106221. https://doi.org/10.1016/i.oceaneng.2019.106221

[10] Weymouth, Gabriel David, Robert Vance Wilson, and Frederick Stern. "RANS computational fluid dynamics predictions of pitch and heave ship motions in head seas." Journal of ship research 49, no. 2 (2005): 80-97. https://doi.org/10.5957/jsr.2005.49.2.80

[11] Kandasamy, Manivannan, Seng Keat Ooi, Pablo Carrica, Frederick Stern, Emilio F. Campana, Daniele Peri, Philip Osborne, Jessica Cote, Neil Macdonald, and Nic de Waal. "CFD validation studies for a high-speed foil-assisted semiplaning catamaran." Journal of marine science and technology 16, no. 2 (2011): $157-167$. https://doi.org/10.1007/s00773-011-0120-7

[12] Avis, John. "Use of antipitch hydrofoil to reduce added resistance of a yacht in waves." Marine Technology and SNAME News 28, no. 01 (1991): 14-22. https://doi.org/10.5957/mt1.1991.28.1.14 
[13] Dwiputera, Haekal, Naufal Yudha Prawira, Muhammad Arif Budiyanto, and Muhammad Arif. "Effect of Angle of Attack Variation of Stern Foil on High-Speed Craft on Various Speed with Computational Fluid Dynamics Method." International Journal of Technology 11, no. 7 (2020): 1359-1369. https://doi.org/10.14716/ijtech.v11i7.4467

[14] Hou, Hongbo, Mateusz Krajewski, Y. Kaan Ilter, Sandy Day, Mehmet Atlar, and Weichao Shi. "An experimental investigation of the impact of retrofitting an underwater stern foil on the resistance and motion." Ocean Engineering 205 (2020): 107290. https://doi.org/10.1016/i.oceaneng.2020.107290

[15] Touw, Michel. "Prediction of the longitudinal stability and motions of a hydrofoil ship with a suspension system between the wings and the hull using a state-space model." (2020).

[16] Sclavounos, Paul D., and Henning Borgen. "Seakeeping analysis of a high-speed monohull with a motion-control bow hydrofoil." Journal of ship research 48, no. 02 (2004): 77-117. https://doi.org/10.5957/jsr.2004.48.2.77

[17] Inukai, Yasuhiko, Koutarou Horiuchi, Takeshi Kinoshita, Hiromasa Kanou, and Hiroshi Itakura. "Development of a single-handed hydrofoil sailing catamaran." Journal of marine science and technology 6, no. 1 (2001): 31-41. https://doi.org/10.1007/s007730170005

[18] Hagemeister, N., K. Uithof, B. Bouckaert, and A. Mikelic. "Hull Vane ${ }^{\circledR}$ versus Lengthening, a comparison between four alternatives for a $61 \mathrm{~m}$ OPV." In FAST Conference. 2017.

[19] Syahrudin, Muhamad Fuad, Muhammad Arif Budiyanto, and Muhammad Aziz Murdianto. "Analysis of the Use of Stern Foil on the High Speed Patrol Boat on Full Draft Condition." Evergreen 7, no. 2 (2020): 262-267. https://doi.org/10.5109/4055230

[20] Murdianto, Muhammad Aziz, Muhammad Arif Budiyanto, and Muhamad Fuad Syahrudin. "Application of stern foil on full draft patrol vessel at high speed condition using computational fluid dynamics (CFD) method." In AIP Conference Proceedings, vol. 2255, no. 1, p. 020023. AIP Publishing LLC, 2020.

[21] Budiyanto, Muhammad Arif, Muhammad Aziz Murdianto, and Muhamad Fuad Syahrudin. "Study on the Resistance Reduction on High-Speed Vessel by Application of Stern Foil Using CFD Simulation." CFD Letters 12, no. 4 (2020): 35-42. https://doi.org/10.37934/cfdl.12.4.3542

[22] Daskovsky, Mark. "The hydrofoil in surface proximity, theory and experiment." Ocean engineering 27, no. 10 (2000): 1129-1159. https://doi.org/10.1016/S0029-8018(99)00032-3

[23] Sacher, Matthieu, Mathieu Durand, Elisa Berrini, Frédéric Hauville, Régis Duvigneau, Olivier Le Maitre, and JacquesAndré Astolfi. "Flexible hydrofoil optimization for the 35th America's Cup with constrained EGO method." Ocean Engineering 157 (2018): 62-72 https://doi.org/10.1016/j.oceaneng.2018.03.047

[24] AirfoilTools.com NACA 4412, accessing on January 2021

[25] CCIT Group Indonesia CFDSOF, http://www.ccit.co.id accessing on January 2021

[26] ITTC (2008) ITTC - Recommended Procedures and Guidelines ITTC - Recommended Procedures and Guidelines

[27] Budiyanto, Muhammad Arif, Muhamad Fuad Syahrudin, and Muhammad Aziz Murdianto. "Investigation of the effectiveness of a stern foil on a patrol boat by experiment and simulation." Cogent Engineering 7, no. 1 (2020): 1716925. https://doi.org/10.1080/23311916.2020.1716925

[28] Bouckaert, B., K. Uithof, N. Moerke, and P. G. Van Oossanen. "Hull Vane on 108m Holland-Class OPVs: Effects on Fuel Consumption and Seakeeping." In Proceeding of MAST Conference. 2015.

[29] Uithof, K., B. Bouckaert, P. G. van Oossanen, B. Eng, and N. Moerke. "A cost-benefit analysis of Hull vane application on motor yachts." (2016).

[30] Vorus, William S. Hydrodynamics of planing monohull watercraft. Springer International Publishing, 2017. https://doi.org/10.1007/978-3-319-39219-6 